\title{
DEVELOPING COUNTRIES IN PUBLIC PROCUREMENT MARKETS: A FOCUS ON SME CAPABILITIES
}

\author{
Barbara Ann Allen and Francis Ssennoga*
}

\begin{abstract}
In Uganda, under current procurement arrangements, few domestic firms are fully competitive. Most of these firms, just like in many other developing countries, are small and medium sized. These SMEs face obstacles at every stage such as poor production techniques, lack of expertise, and the lack of information about potential contracts. For firms to succeed in the global market there is a need for them to understand their internal capabilities with regard to bidding for public procurement contracts. This paper presents the results of a recent research study on SME capacity in Uganda to bid for and win international contracts. It suggests and tests key components of SME capacity that will need further attention if Ugandan firms are to improve in terms of participation in the public procurement market.
\end{abstract}

\section{INTRODUCTION}

Over the last two decades, market access for exports from developing countries has improved as a result of multilateral trade liberalisation, regional trade arrangements and non-reciprocal preferential trading arrangements (Jebuni 2006). For these countries to further expand their exports there is a need for them to extend their markets - to not only consider traditional exports but to widen the scope to include other markets through bidding for international public procurement contracts.

* Barbara Ann Allen, Ph.D., is a Lecturer, School of Public Policy, University of Birmingham, Edgbaston, Birmingham, West Midlands, United Kingdom. Francis Ssennoga, a Ph.D. candidate, is a Lecturer, Department of Business Studies, Kyambogo University, Kampala, Uganda.

Copyright @ 2008 by Barbara Ann Allen and Francis Ssennoga 
For firms to succeed in the global market there is a need for them to survey their internal capabilities as part a wider strategy to become competitive in terms of their bidding capacity and ability to be active internationally. The SMEs face obstacles at every stage. They must surmount many problems such as: lack of information about potential contracts, inability to draw up business plans, mismatch between the size of the enterprise and the large size of many contracts, anxiety about currency fluctuations, and the need to meet standards, certification and qualification requirements. Other problems, such as delays in payment, may arise in the post award stage.

Drawing from a major empirical study on SMEs from Uganda, this paper focuses on building and critically assessing internal constraints related to procurement capacity amongst Ugandan firms. First, the paper presents a literature review that begins to uncover elements for consideration as 'supply side inhibitions' or potential barriers to the improvement of firms' capacity for bidding internationally. Second, we look at the actual performance of our Ugandan firms in terms of their supplying behaviour and export performance. Third we present some interview data with a view to building a picture of our firms and their key capacity issues. Fourth we empirically examine four derived variables in terms of their correlation to global competitiveness and test the derivations. Finally we make some conclusions about the state of Ugandan SMEs and where further attention needs to be paid in the effort to increase firm capacity to capture international public procurement contracts.

\section{LITERATURE REVIEW}

Our literature review was aimed at helping to identifying potential variables that could be considered in terms of assessing firm capacity for bidding for contracts internationally. We first turn to looking at work associated with firm competitiveness and factors underpinning competitiveness generally. Various researchers have explored factors affecting global competitiveness of firms. Javalgi et al (2003) identified firm size, competitive advantages and market characteristics as crucial factors in the global competitiveness of firms. Axinn and Matthyssens (2001) go further by identifying competitive factors as firm size, operating efficiency, product development capability, knowledge of 
foreign customer requirements, personnel knowledge and training, quality control processes plus production methods and technology.

The notion of competitive advantage is an important concept in this field and the questions about what makes a firm better equipped than other firms to be globally competitive. Katsikeas (1994), underscores the importance of competitive advantage to the global competitiveness of firms, and examines a number of variables that constitute this specifically. These are production method and technology, quality control process, new product development capability, range of products offered, personnel experience and training, operating efficiency, importers distribution network, export market knowledge, company reputation, promotional efforts, assessment of export market developments, personal contact with overseas distributors, proximity to export market, product quality, product uniqueness, price competitiveness and cost of raw materials. From this research, four competitive dimensions were synthesized: production capability, market capability, product superiority and competitive pricing. Katsikeas notes that there is a lack of empirical research concerned with a systemic examination of the elements that make up a firm's export competitive profile. This is important in that a firm's procurement capacity - or ability to bid and win procurement contracts - will have much to do with their interest and capacity to export. Winning public procurement contracts is a key route to building structural capacity for exportation.

Export performance and its components may be an indicator of procurement capacity. The literature looks at export performance from a number of angles. While not differentiating between suppliers to governments and suppliers to private firms, Ortega and Alamo-Vera, (2005) classify determinants to a firm's export behaviour into external environment level and the firm level. They explain that external environment level factors include macro-economic and industry characteristics that individual exporters can only control to a limited extent, while at firm level, organisational determinants like structural and behavioural aspects within the firm are considered. These structural and behavioural aspects include firm size, operating efficiency, product development capability, knowledge of foreign customer requirements, personnel knowledge and training, quality control processes plus production methods and technology. In our study, we wanted to focus in on the internal firm level factors, given that individual firms - certainly 
in the Ugandan context - can not affect external factors in the short to medium term.

The literature supports this separation of internal and external export performance factors(see for example Aaby and Slater, 1989). Zou and Stan's research (1998) explains that classifying the determinants of export performance into internal and external factors is theoretically justified as the two categories correspond to different theoretical bases. Specifically, internal determinants are justified by the resource-based theory, while external determinants are supported by the industrial organization theory. Quoting Barney (1991), Zou and Stan argue that the resource-based theory conceives a firm as a unique bundle of tangible and intangible "resources" (assets, capabilities, processes, managerial attributes, information, and knowledge) that are controlled by a firm that enable it to conceive and implement strategies aimed at improving its efficiency and effectiveness. The resource-based theory contends that the principal determinants of a firm's export performance and strategy are the internal organization resources.

These internal organization resources have an important behavioural element, aspects of which may promote or constrain the firm's prospects. The attitudes and perceptions of management have been cited as important determinants of export performance. Cavusgil \& Zou (1994) explain that the decision maker's capacity to perceive and interpret signals from the market has a fundamental bearing on the decision of whether or not to export. Relatedly, management export commitment allows firms to aggressively go after export opportunities (Zou and Stan 1998). In terms of procurement capacity, an aggressive and capable firm would move fast once a public contract has been advertised and thus potentially venturing into bidding internationally. Management perceived advantages such as believing that a new bid and consequent exports would increase profits promotes an exporting spirit while perceived barriers like risks, costs and complexity may reduce the propensity to export.

Another key factor that emerges from the literature related to procurement capacity is firm ability to cooperate and build relationships. The extent to which firms can leverage their resources by interacting with other firms and forming cooperative relationships has an important impact on their capacity for winning new contracts. Firm relationships can be defined as a an arrangement where two firms form strong 
extensive social, economic, service and technical ties with the intent of lowering total costs/or increasing value, thereby achieving mutual benefits(Anderson and Narus 1991). Style and Amber (1994) developed a relationship paradigm showing the importance for export performance of relationships and interactions with key suppliers and customers along with other network members such as distributors and market agencies. Becoming part of a network indicates both internal strength for a firm, in terms of understanding its potential for capacity building, and the recognition and acceptance by other firms may indicate a level of maturity that will enable the firm to enter into bigger and more sophisticated contracts. Firms have generally been found to engage in alliances in order to achieve one or more of the following: access to markets; accelerate the return on investments, share the cost of investments such as research and development; spread risk, access resources such as complementary technologies; create efficiencies through economies of scale and scope and through rationalization; open up otherwise unattainable investment options; and co-opt competition (Arvanitis and Vonartas 2000)

The affiliation to consortia by small firms for technological development, promotion and sales, permits them to share resources and experience, thereby simplifying entry into foreign markets (Toni and Nassimbeni 2001). Toni and Nassimbeni affirm that utilisation of external services, fosters internal capacity which a small company alone would be unlikely to achieve. These cover critical areas such as product design and technological development where small companies may not possess competency. DeToni and Nassembeni(2001), in a study consisting of 165 small manufacturing companies, find that the role of inter-organisational relationships is critical, especially the connections to consortia and the use of external services. By affiliating to consortia for technological development and promotion and sales, the smaller firms can share resources and experience with one another and larger firms in the consortia which simplifies their entry into foreign markets. The use of external services allows for internal improvements, for example in product design and technological developments, where a small firm might not have competencies or be able to achieve. Product inferiority has an important impact on a firm's readiness to compete on an international level - the use of sub-standard parts from local suppliers invariably results in the firm's inability to produce high-quality products (Gosen, Babbar \& Prasad, 2004). The use of collaborative relationships 
and linkages could help to raise the collective knowledge about product problems and begin to lessen the impact.

However Reuber and Fischer, (1987) in Bishop (2000) argue that small firms often find it difficult to fund the substantial costs involved in establishing new collaborative arrangements including the costs of searching for a partner and negotiating an arrangement. They may also lack experienced managers who have an understanding of operating in diverse markets. This is likely to be particularly acute for overseas cooperation, which often involves substantial cultural and attitudinal differences amongst potential partners. Culture and attitudinal differences build from experience and educational attainment and certainly are critical in terms of firm capacity and potential.

The efficiency of the firm itself will have an important impact on its capacity for bidding for international contracts. Soderbom and Teal (2001, in Fafchamps et al. 2002) find that worker's schooling and experience is not what drives exports per se, but it is the underlying efficiency with which the firms operate that is the stronger determinant of exports. To achieve efficient production methods, emphasis on research and development needs to be emphasised - in order to translate it into competitive advantage. Research and development is one of the forces at work in transforming capabilities into competitive and comparative advantage (Wattanaprattipaisan 2002). Badagawa (2002) from the Private Sector Foundation Uganda, when discussing supporting firm level competitiveness in Uganda also very clearly pointed out that research and development is a key requirement for productivity enhancement and catch-up. Whether Ugandan firms have the capacity and motivation to engage in R\&D may be an illuminating element in terms of their engaging in international activity.

\section{METHODOLOGY}

\section{Sampling Procedures}

Indigenous firms currently involved in domestic public procurement to central government were the focus of this study and provided the target population. Our focus on these firms for the study population was based on our assumption that if these firms can bid for contracts internally, then they would be interested in extending their business to foreign countries save for the constraints they may be facing. A list of 
these suppliers was sourced through the Public Procurement and Disposal Authority (PPDA). This list had a total of 2757 suppliers to government. This list may not have been exhaustive because of some suppliers who have not yet registered with PPDA despite the requirement to do so. It was never-the-less, quite comprehensive. For example, the Uganda National Association of Building and Civil Engineering Contractors (UNABCEC) has a list of all engineering and construction firms in Uganda. It was discovered that out of the 256 UNABCEC members only 6 were not listed by PPDA as supplying to various government ministries and Departments. However many of the firms listed by PPDA are inactive and records indicated that some had not bid for any contract in 2005 which was our year of study. Our target population was made up of those firms currently supplying to government. In order to weed out sporadic suppliers to government contacts, we tallied their (suppliers) participation rate in bidding for the contracts in the year 2005 and those with a frequency of less than 10 were dropped.

Consequently, our study population was reduced to 614 active firms. We then categorised these firms into three domains: supplies, works and services. This led to 304 suppliers of goods, 251 suppliers of services and 86 suppliers of works. Under supplies, the research undertook an initial survey of firm capabilities with a view to assessing which goods could be supplied to the international public sector by local firms. Uganda is mainly an agricultural country and most of its commodities are agriculture-related, which do not form a big part of the competitive public procurement market. This research considered firms that supply pharmaceuticals, steel roads and construction materials plus foam products to public sector firms especially in East Africa. This resulted in the study population for supplies to be reduced to 86 firms.

Uganda has only 10 pharmaceutical firms and only 6 foam manufacturers. Because of this small size all of them were targeted under the supplies domain. We then added 12 steel rods and construction material manufacturers that were chosen randomly, constituting a sample of 28 firms under the supplies category. For the works and services domain we made a random selection from the study population. We identified 40 works firms and 50 services firms making our total sample space for this research to be 118 firms. 


\section{Research Design}

The overall research design consisted of two strategies, a cross sectional survey of various firms currently supplying to government of Uganda together with qualitative interview research undertaken to give a critical assessment of the identified factors. This research design, combining survey methodology and qualitative interview study was used due to the argument that multi-method approach enables triangulation to take place. Further, since each method has different effects and it may be impossible to ascertain the nature of that effect. Use of different methods cancels out the 'methods effect' and leads to greater confidence being placed on the conclusion (Saunders et al 2003)

Two methods of data collection were used, questionnaire and interview. The items included in the questionnaire were extracted from extant literature on global competitiveness and an initial pilot study among Ugandan firms. These were extensively pre-tested among industry executives and refined to ascertain the comprehensiveness and phrasing of the relevant questions. On a likert point scale of 1 to 5 , ranging from 'strongly disagree' to 'strongly agree', Uganda firms were asked to gauge their capabilities on each of the items identified that signify their global competitiveness in the international public procurement markets. Our main respondents were the Chief executive officers of the firms sampled or in their absence Chief procurement officers.

In total, under supplies out of the 28 questionnaires distributed, 17 questionnaires were returned signifying a $64.2 \%$ success rate. For supplies, twenty-seven firms returned their questionnaire signifying a response success rate of $57 \%$ and for works, we received a response rate of $77.5 \%$ having received 31 questionnaires back.

An interview guide was developed and fifteen CEOs were interviewed, spanning the three areas of suppliers, works and services. The composition of those sampled was four firms from Construction, four firms from services and seven firms form Supplies. For supplies we specifically sampled two manufacturers of Steel rods and Building materials, three were Pharmaceuticals and two were manufacturing form products. Specifically interviews were conducted to build further understanding of firm level inhibitions identified and determine how these challenges could be addressed. 


\section{ANALYSIS AND DISCUSSION OF FINDINGS}

\section{Performance of Ugandan Firms In International Public Sector Procurement}

Before specifically outlining and examining the constraints relating to Ugandan firms' failure to bid internationally, we first established their current performance in the world market. We asked the sampled firms about their current participation in export trade and their involvement foreign public procurement markets. We also were also interested in knowing the countries they exported to.

As the table below indicates, out of 69 firms spanning the three domains of supplies, works and services, only 29 firms constituting a percentage of $42 \%$ is involved in exportation. However, out of the 29 exporting firms, only 10 or $14.5 \%$ of all sampled firms are involved in bidding for foreign public sector contracts. None of the sampled service firms has bid for foreign contracts. The analysis further indicates that exportation is concentrated in the East African region with only a few firms indicating exportation into USA and Europe.

None of the 10 firms that have bid and won foreign contracts has ever done so for public contracts advertised in Europe and USA. This agrees with Salinger (2001), who says that African firms prefer exporting to regional neighbours. The underlying reason is that regionally, firms are not subjected to the same competitive pressure of product development, quality, customer responses, and technology as firms which export to global clients.

TABLE 1

Ugandan's Firms Performance in the World Economy

\begin{tabular}{|l|c|c|c|c|l|}
\hline Category & $\begin{array}{c}\text { \# of } \\
\text { Responses }\end{array}$ & Exporters & $\begin{array}{c}\text { Supply to } \\
\text { Foreign } \\
\text { Govern- } \\
\text { ments }\end{array}$ & $\mathbf{\%}$ & Countries Exported To \\
\hline Works & 16 & 5 & 5 & 31.25 & Tanzania, DRC, Southern Sudan \\
\hline Services & 28 & 3 & 0 & 0 & $\begin{array}{l}\text { Mozambique, Denmark, East } \\
\text { Africa, USA, }\end{array}$ \\
\hline Supplies & 25 & 21 & 5 & 20 & $\begin{array}{l}\text { DRC, Australia, East Africa, } \\
\text { Egypt, Sudan, Namibia, Germany }\end{array}$ \\
\hline Total & $\mathbf{6 9}$ & $\mathbf{2 9}$ & $\mathbf{1 0}$ & & \\
\hline
\end{tabular}


To further understand this dismal performance, we conducted interviews which attempted to uncover the underlying problems CEOs face. Their responses were wide ranging and intriguing. At firm level many firms blamed it on the cost of production, specifically, labour. They reported that local labour in Uganda is very expensive compared to the regional neighbours like Kenya, and Tanzania. According to some respondents, Ugandan workers are lazy and lack innovativeness. When asked whether staff were committed to their work and were involved in generating new ideas, one respondent derisorily expressed his discontent, "It is challenging to get quality work from Ugandans. They are empty headed with no ideas; they lack practical experience and are never hard workers." He explained that they either come too late to work or leave too early, waste the whole day away and need very close supervision. "How you can get work for the international market from such people?" he asks. Another respondent reported that, "our strength in this organisation is that we have qualified staff and we employ them on merit. Our weakness is that workers tend to relax and fail to deliver in the way required." While another respondent commented, "the employees are slow and often lazy in their work." Inspite of these complaints about the labour force at least one respondent had a positive assessment, reporting that "The quality of our products is high, we have a good reputation, and our staff do their work professionally." There is undoubtedly potential within some Ugandan firms.

However other respondents do not entirely put the blame on the labour force. Respondents said that the duties charged on machines by customs authorities are very high. So with meagre resources, buying new machinery to improve the production process becomes an insurmountable challenge given that even the cost of finance is very expensive with interest rates being as high as 25\%. This derails any possible form of expansion.

On the issue of exportation to only regional neighbours and not venturing to other countries, the reason is both strategic and structural. At the strategic level firms are very hesitant to look further afield, so their plans remain regional. One respondent expounds this by saying; "We are aiming to be more of an East African company; a strong regional company and improve on outward business in terms of the region." While another comments, "We are expecting to be more than a Ugandan company within a period of five years - the company will be exporting more, first within the region and will be improving its 
portfolio." Another respondent showed ambition by saying, "we are aiming to make a difference in the market and investing to build local capacity."

At structural level firms are conscious of their incapacity to meet international requirements. When asked whether firms have an elaborate written policy on bidding internationally, one firm responded "No, we don't have a bid process written down but bid based on past experience. In most cases we focus on our organizational ability to execute the contract and even then we limit ourselves to the region." Another firm wondered why they would want to go to foreign markets, when they lack capacity even to compete internally.

Many firms were in agreement that they could not meet international requirements. These requirements included quality standards, specification issues and contact execution. One respondent said, "With poor infrastructure in the country, the work ethic of the Ugandan labour force and operational inefficiencies, it is absolutely impossible to meet the strict compliant conditions that western capitals set up."

The literature review, the quantitative data on current performance, combined with the information gleaned from the interview process resulted in a number of elements that could shed light on the extent to which Ugandan firms have the capacity to bid for, and win international government contracts. We reduced the information into four key categories: readiness of firms (organisational strategy including exporting, organisational culture, labour and workforce attitudes), entrepreneurial capabilities (leadership, innovativeness, R\&D, willingness to risk), firm external linkages (acquiring resources, collaborating, use of consortia, external relationships for export strategy), and internal firm competitiveness (efficiency of production, product enhancement and improvement, awareness of market opportunities). We tested each component against a control variable defined as 'global competitiveness' to examine the extent to which the components were correlated with the capacity to bid and win international government contracts. 
FIGURE 1

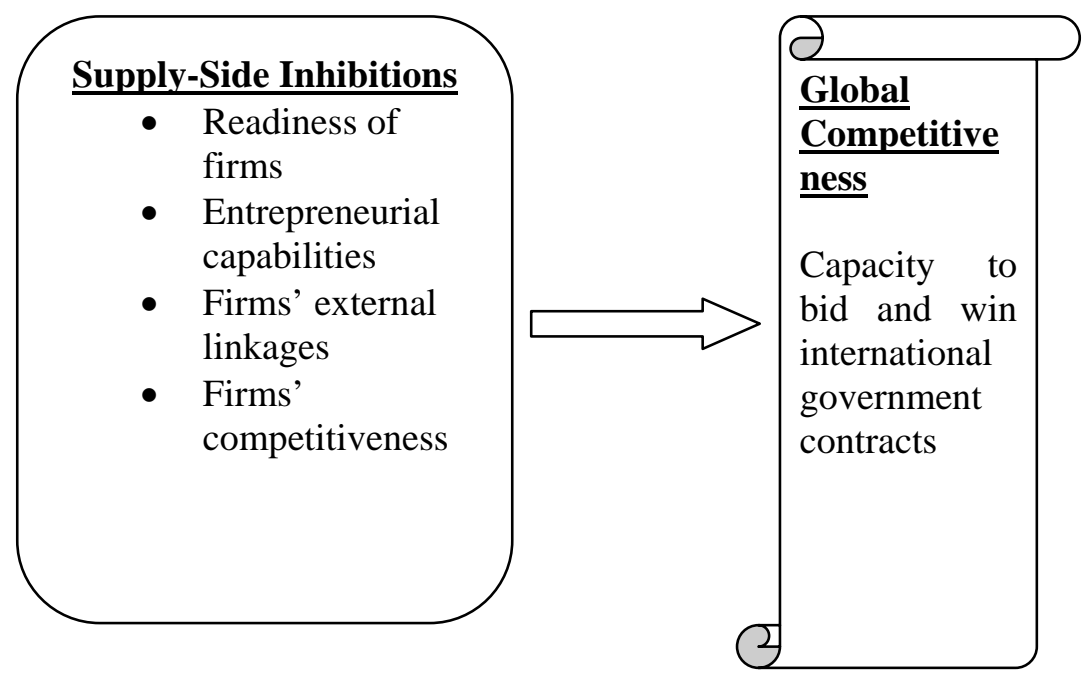

\section{COMPONENT MEASURES}

\section{Firm Readiness}

The right organisational culture and attitude may play a significant role in a firm's ability to bid and win foreign public procurement contracts. The eagerness and positive outlook to enter international markets may significantly influence a firm to do so. From a list of 10 indicators of organisational readiness the association of firm readiness to global competitiveness was measured. The questions tested for association were in regard to timely acquisition of information regarding advertised foreign contracts, attitude of workers towards bidding for the international contracts, organisational culture, embedment of bidding for foreign contracts as part of the organisational strategy, work ethic, unpredictability of local market as a motivator for expanding their market and risk averseness. The Pearson correlation result indicates a very high positive correlation $(r=.904, p<0.01)$ implying that a firms readiness is highly correlated to its global competition. 
TABLE 2

Showing the Correlation between Readiness and Global Competitiveness

\begin{tabular}{|l|l|c|c|}
\hline & & Readiness & $\begin{array}{c}\text { Global } \\
\text { Competitiveness }\end{array}$ \\
\hline Readiness & Pearson Correlation & 1 & $.904(* *)$ \\
\hline & Sig. (2-tailed) & & .000 \\
\hline & $\mathrm{N}$ & 67 & 67 \\
\hline Global Co & Pearson Correlation & $.904(* *)$ & 1 \\
\hline & Sig. (2-tailed) & .000 & \\
\hline & $\mathrm{N}$ & 67 & 67 \\
\hline
\end{tabular}

Notes: ${ }^{* *}$ Correlation is significant at the 0.01 level (2-tailed).

\section{Entrepreneurial Capabilities}

A vibrant entrepreneurial spirit in the international market may open new opportunities. Firms have to be able to identify opportunities, seize them and dare to find niches in the world markets. There is need for creativity and determination in order to gain access to global public procurement markets. The personal character of the owner/manager may impact heavily on a firm's operations. There may be need for the owner to have personal charisma to propel and push a firm into the international markets. A 14-question tool was used to measure this component among Uganda firms. Our questions tested the specific character required of globally competitive firm, asking about the executive or manager's style in terms of dynamism, innovativeness and leadership. The questions also tested an the leader's willingness to undertake risk, the extent of his or her ambition, whether there was a clash between person ambition and the organisational mission, dedication, innovativeness, openness to change, involvement of staff, and whether there was environment conducive to idea generation. The Pearson correlation result indicates that entrepreneurship and global competitiveness are fairly correlated $\left(r=.580, \mathrm{p}^{<.01}\right)$. 
TABLE 3

Showing Correlation of Entrepreneurship and Global Competitiveness

\begin{tabular}{|l|l|c|c|}
\hline & & $\begin{array}{c}\text { Entrepreneur- } \\
\text { ship }\end{array}$ & $\begin{array}{c}\text { Global } \\
\text { Competitiveness }\end{array}$ \\
\hline Entrepreneurship & $\begin{array}{l}\text { Pearson } \\
\text { Correlation }\end{array}$ & 1 & $.580\left(^{* *}\right)$ \\
\hline & Sig. (2-tailed) & & .000 \\
\hline & $\mathrm{N}$ & 78 & 67 \\
\hline $\begin{array}{l}\text { Global. } \\
\text { competitiveness }\end{array}$ & $\begin{array}{l}\text { Pearson } \\
\text { Correlation }\end{array}$ & $.580\left(^{* *}\right)$ & 1 \\
\hline & Sig. (2-tailed) & .000 & 67 \\
\hline & $\mathrm{N}$ & 67 & 67 \\
\hline
\end{tabular}

Note: ** Correlation is significant at the 0.01 level (2-tailed).

\section{External Linkages}

Organizations link up with suppliers and other partners in value chain in order to acquire external resources to produce products/services at competitive prices, adjusted for quality such that they can attract and retain customers. Firms have limited resources, such that the social linkages may create the required infrastructural support for the attainment of the global competitiveness. From a set of 8 questions, Ugandan firms were asked about their effort to set up linkages both domestically and internationally, their assessment of these linkages, whether or not they attribute these linkages to the success of international bids, inclusion of external linkage as part of their export stategy and effort undertaken to manage their linkages. The Pearson correlation result indicates that External linkage and global competitiveness are strongly correlated $(\mathrm{r}=.659, \mathrm{p}<.01)$. 
TABLE 3

Showing Correlation Values between External Linkage and Global Competitiveness

\begin{tabular}{|l|l|c|c|}
\hline & & $\begin{array}{c}\text { External } \\
\text { Linkage }\end{array}$ & $\begin{array}{c}\text { Global } \\
\text { Competitiveness }\end{array}$ \\
\hline External Linkage & $\begin{array}{l}\text { Pearson } \\
\text { Correlation }\end{array}$ & 1 & $.659\left(^{* *}\right)$ \\
\hline & Sig. (2-tailed) & & .000 \\
\hline & $\mathrm{N}$ & 74 & 67 \\
\hline $\begin{array}{l}\text { Global } \\
\text { Competitiveness }\end{array}$ & $\begin{array}{l}\text { Pearson } \\
\text { Correlation }\end{array}$ & $.659\left(^{* *}\right)$ & 1 \\
\hline & Sig. (2-tailed) & .000 & \\
\hline & $\mathrm{N}$ & 67 & 67 \\
\hline
\end{tabular}

Note: ** Correlation is significant at the 0.01 level (2-tailed).

\section{Internal Competitiveness}

Competitiveness is the effectiveness in the production and delivery of goods and services at lower cost than those of the competitors. It is the effect of learning, upgrading, differentiated quality, continuous product enhancement, design and delivery. It arises from transforming core capabilities into competitive advantage. Through a set of 10 questions we examined marketing versatility and efficient production methods including the efficiency of production methods, new product development processes, operational efficiency, awareness of market opportunities, brand image, competitive pricing and the strength (or existence of) a marketing team. The Pearson correlation result indicates that internal competitiveness and global competitiveness are strongly correlated $(\mathrm{r}=.822 \mathrm{p}<.01)$. 
TABLE 4

Showing Correlations Between Internal Competitiveness And Global Competitiveness

\begin{tabular}{|l|l|c|c|}
\hline & & $\begin{array}{c}\text { Internal } \\
\text { Competitiveness }\end{array}$ & $\begin{array}{c}\text { Global } \\
\text { Competitiveness }\end{array}$ \\
\hline Internal Competitiveness & Pearson Correlation & 1 & $.822\left(^{* *}\right)$ \\
\hline & Sig. (2-tailed) & & .000 \\
\hline & $\mathrm{N}$ & 75 & 67 \\
\hline Global competitiveness & Pearson Correlation & $.822\left(^{* *}\right)$ & 1 \\
\hline & Sig. (2-tailed) & .000 & \\
\hline & $\mathrm{N}$ & 67 & 67 \\
\hline
\end{tabular}

Note: ${ }^{* *}$ Correlation is significant at the 0.01 level (2-tailed).

\section{Global Competitiveness}

Twenty questions were devised to test whether Ugandan firms believed they are globally competitive so as to export and more especially to bid for foreign public sector contracts. The variance of global competitiveness per sector was also explored. Firms were asked to indicate how strongly they agree with questions concerning their global competitiveness to bid and win international public procurement contracts on a 5-point likert scale. These questions spanned : quality of product, conformance of products to international standards, product porttofolio, workers experience, cost of raw material competitveness, product uniqueness, techological adaptation and strong production control. At the sectoral level, with the exception of the service sector that indicated a fairly high level of global competitiveness, the other two sectors showed dismal competitiveness with only 7.6 above the median of 50 for supplies and 5.2 above the median same median of 50 .

TABLE 5

Showing Sectoral Mean Scores for Global Competitiveness

\begin{tabular}{|l|r|r|r|r|}
\hline Sector & \multicolumn{1}{|c|}{ Minimum } & Maximum & \multicolumn{1}{c|}{ Mean } & Std. Deviation \\
\hline Service & 20.00 & 88.00 & 65.6154 & 18.58618 \\
\hline Supplies & 24.00 & 78.00 & 57.6071 & 14.58142 \\
\hline Works & 15.00 & 77.00 & 55.2222 & 21.46832 \\
\hline
\end{tabular}


TABLE 6

Showing Mean Score for Global Competitiveness

\begin{tabular}{|l|r|r|r|r|r|}
\hline & $\mathrm{N}$ & Minimum & Maximum & Mean & $\begin{array}{c}\text { Std. } \\
\text { Deviation }\end{array}$ \\
\hline $\begin{array}{l}\text { Global. } \\
\text { competitiveness }\end{array}$ & 67 & 24.00 & 81.00 & 66.3284 & 15.46392 \\
\hline Valid N (listwise) & 67 & & & & \\
\hline
\end{tabular}

The overall global competitiveness of firms calculated as a single unit was done. The highest expected value was 100 while the lowest expected value was 20 with median was 50 . The findings showed the mean global competitiveness was $66.3, \mathrm{SD}=15.46$. The minimum value was 24 while the maximum was 81 . Although the independent variables indicated need for enhancement, the overall global competitiveness of firms indicates a fairly adequate performance being 16.3 above the median. When examined as a whole unit firms tend to be more competitive.

\section{Mean Score for The Independent Variables}

A mean score on the 4 independent variables was perceived to indicate a firm's strength to compete globally. As the table below indicates, the mean score for the three variables (other than entrepreneurship) was either a few points below the median score or below measured on a 5-likert scale.

On the element of readiness, the mean score $(X=28.97$, s.d $=11.9)$ was only 3.9 points above the median score of 25 , on a 5 - point scale of 10 items. This implies that Ugandan firms are not yet ready to compete in the global economy. The firms lack the right attitude and aggressiveness to bid for foreign contracts.

The situation is however different for entrepreneurship capabilities. The mean score $(X=48.04$, s.d $=12.58)$ was 13.04 points above the median score of 35, on a 5- point scale of 14 items indicating a relatively sufficient level of capabilities amongst Ugandan entrepreneurs. This might indicate that Ugandan have the charisma and aptitude to compete globally but they are only let down by other factors, such as lack of linkages, lack of resources and commitment of staff to take the necessary risks to bid for international contracts. 
The mean score for external linkages was ( $X=23.91$, s.d $=7.43$ ), 3.9 points above the median score of 20, on a 5- point scale of 8 items indicating a relatively low level of external linkage creation. For the element of internal competitiveness, the mean score $(X=27.24$, s.d $=13.8$ ) was 2.24 points above the median score of 25 , on a 5 - point scale of 10 items indicating a relatively low level of Internal competitiveness.

TABLE 7

Showing The Mean Scores On The Major Variables

\begin{tabular}{|l|c|c|c|c|c|}
\hline & $\mathrm{N}$ & Minimum & Maximum & Mean & $\begin{array}{c}\text { Std. } \\
\text { Deviation }\end{array}$ \\
\hline Entrepreneurship & 78 & 10.00 & 63.00 & 48.0385 & 12.58059 \\
\hline $\begin{array}{l}\text { Internal } \\
\text { competitiveness }\end{array}$ & 75 & .00 & 46.00 & 27.2400 & 13.80055 \\
\hline External Linkage & 74 & .00 & 32.00 & 23.9054 & 7.43404 \\
\hline Readiness & 67 & .00 & 46.00 & 28.9701 & 11.91761 \\
\hline
\end{tabular}

\section{CONCLUSIONS}

Involvement in international public procurement markets for firms from developing countries remains problematic. Certainly Uganda is dominated by SMEs that are challenged on a number of levels to improve their products, increase the performance level of their workforce, and translate their potential into successful bids. Part of the problem for SMEs and competing favourably, lies in the high costs of production arising out of poor production techniques and lack of expertise. This leads to uncompetitive products from developing countries in terms of quality and price compared to those from developed nations. There is a difference in perception of quality and of what it takes for a product to be able to effectively compete in global markets between people in developing countries and those in the industrialized world (Madu, 1997). The economies of many developing countries have historically been protected through government regulations and significant import duties. As such, people constituting the workforce remain unexposed to the kinds of choices available to consumers in industrialised countries and thus fail to comprehend the level of quality it takes to satisfy demanding consumers in open and intensely competitive 
world markets. This signals that there are internal structural and behavioural issues in Ugandan firms that need to be addressed.

The research established that very few Ugandan firms are supplying to foreign governments, and those that are, are mainly involved in the East Africa region. Through an examination of the literature and supported by interview data, we proposed four variables to test against another variable called 'global competitiveness', further defined for this paper as the capacity to bid for and win international public procurement contracts. There were correlations between all four variables and global competitiveness, with the strongest correlations between internal competitiveness and firm readiness, and global competitiveness. Further testing showed that our Ugandan firms have significant limitations with respect to readiness, external linkages and internal competitiveness they have capability gaps in these areas. Interestingly, the firms show a high level of entrepreneurial capabilities in the context of this study which leads to the conclusion that the motivation and interest exists to expand into other markets but that this is constrained by other factors.

Plugging into the global economy is a question of becoming an attractive export production platform to attract foreign investors and subcontractor interests, who then bring with them the product specifications already designed for the foreign markets. Whilst detailed knowledge of foreign markets is significantly lacking for most Ugandan firms, this does not necessarily mean that firms can not change, and change quickly to meet the fast paced global economy. This detailed market knowledge should be pursued at both government and institutional level so as to develop trade strategies (Uganda Service Sector Export Strategy 2005). For the most part developing linkages, both internally amongst competitors, and externally with competitors and purchasers, will be critical to addressing the internal challenges firms face, none of which can be addressed quickly without substantial shift in infrastructure development and resource aggregation.

Fox (2004), when looking at trade capacity building programs describes countries that have performed economic miracles in a generation, (Korea, Taiwan, and Ireland), and suggests that it is not that countries have insufficient elements for export success but that they have lacked catalytic agents that put a cumulative process in motion. It is these external linkages that could be 'catalytic agents' for Uganda and other developing countries. These external linkages once created have 
multiple advantages. For example, Ugandan firms would be in position to learn basics of production specification in terms of labelling, and packaging; but more importantly could be allowed to produce internationally branded goods through an Equipment Manufacturer Licensing Agreement (Salinger, 2001).

Wignaraja (2002) notes that capability building involves cooperation between agents - firms do not acquire capabilities in isolation but must interact and pursue interdependence. Usually firms build on pre-existing technologies, and in so doing, the exchange information with other firms and support institutions. Collective learning can be a key contributor to Ugandan firm capacity. Our study has shown that there are key areas to work on for the Ugandan SME environment, namely in these areas of linkages and internal capacity. Further research will explore in more detail how to begin to deal with some of these capability gaps.

\section{ACKNOWLEDGEMENTS}

The authors would like to thank the sponsors of the project upon which this article is based, the Uganda Programme for Trade Opportunities and Policy (UPTOP) with funds from the European Union. We would also like to thank the Ugandan firms who took part in the research and the assistance of researchers at the Department of Business Studies at Kyambogo University.

\section{REFERENCES}

Aaby, N. \& Slater, S. (1989). "Management Influences on Export Performance: A Review of the Empirical Literature 1987-88." International Marketing Review, 6 (4): 7-26.

Anderson, J.C., Narus, J.A. (1990, January). "A model of distributor firm and manufacturer firm working partnerships." Journal of Marketing, 54: 42-58. 
Arvanitis, R. \& Nicholas Vonortas, S. (2000). “Technology Transfer and Learning Through Strategic Technical Alliances: International Experiences.” The Journal of Technology Transfer, 25 (1): 9-12.

Axinn, C.N. \& Matthyssens, P. (2001). "Limits to Internationalisation Theories In An Unlimited World.” International Marketing Review, 19: 436-449.

Badagawa, G. (2002). "Situational Analysis on Governance: Industrial Governance, Policy Development, Economic and Corporate Governance in Uganda.” Private sector Foundation Working Paper.

Barney, J. (1991, March). "Firm Resources and Sustained Competitive Advantage.” Journal of Management, 17: 99-120.

Bernal, R. L. (2001). “Small Developing Economies in the World Trade Organisation." Paper presented at the World Bank Conference on Leveraging Trade, Global markets Integration and the New WTO Negotiations for Development. Washington, DC, July 23-24.

Bishop, P. (2002). "Competition, collaboration In The Provision Of Public Services: The Case of the UK Defense Sector.” Journal of Finance and Management in Public Services, 3 (1): 13-24.

Cavusgil, S.T., Zou, S. (1994). "Marketing Strategy-Performance Relationship: An Investigation Of The Empirical Link In Export Market Ventures." Journal of Marketing, 58: 1-21.

De Toni, A., Guido Nassimbeni, G. (2001). “The export Propensity Of Small Firms: A Comparison Of Organisational And Operational Management Levers In Exporting And Non-Exporting Units.” International Journal of Entrepreneurial Behaviour \& Research, 7 (4): $132-147$.

Fafchamps, M., Hamine, S., \& Zeufack, A. (2002). "Learning to Export: Evidence from Moroccan Manufacturing.” Working Paper (CSAE WPS/2002-02). Department of Economics, University of Oxford.

Fenster, G. (2003) "Multilateral Talks on Transparency in Government Procurement: Concerns for Developing Countries.” IDS Bulletin, 34 (2): 65-81.

Fox, J. W. (2004). "An Evaluation of Trade Capacity Training Programmes, USAID Behind-the Border Trade Capacity Building.” 
Bureau of Policy and Programmes, PPC Evaluation working Paper No 14 (2004) PN-ACT-169

Gosen, J., Babbar, S., \& Prasad, S. (2005). "Quality and Developing Countries: The Role of International and Organizational Factors." International Journal of Quality \& Reliability Management, 22 (5): 452-464.

Javalgi, R.G., Griffith, D.V. \& White, S.D. (2003). “An Empirical Examination of Factors Influencing tThe Internationalisation Of Service Firms.” Journal of Service Marketing, 17 (2): 185-201

Jebuni C.D. (2006) Challenges and Prospects of relaxing supply side constraint in Africa-Africa Development Bank/AERC Conference presentation on accelating Africa's Development fve years into the 21st Century. Le Raissance Hotel Tunis, Tunisia November 2224(2006)

Katsikeas, C. (1994). "Export Competitive Advantages: The Relevance of Firm Characteristics.” International Marketing Review, 11 (3): 33-53.

Madu, C.N. (2005). "Quality Management in Developing Countries.” International Journal of Quality Sciences, 2 (4): 272-291

Ortega, S.M.S \& Alamo-Vera (2005). “SMEs' Internationalisation: Firms and Managerial Factors." International Journal of Entrepreneurial Behaviour \& Research 11 (4): 258-279

Reuber, R., \& Fisher, E. (1997). "The Influence of the Management Team's International Experience on the Internationalization Behaviors of SMEs.” Journal of International Business Studies, 28 (4): 807.

Salinger, L.B. (2001, June). "Productivity, Comparative Advantage, and Competitiveness in Africa African Economic Policy." African Economic Policy.

Soderbom, M. \& Teal, F., 2001. "Are African Manufacturing Firms Really Inefficient? Evidence from Firm-level Panel Data." Working Papers Series 2001-14. Oxford, UK: Centre for the Study of African Economies, University of Oxford.

Styles, C. \& Ambler, T. (1994). "Successful Export Practice: The UK Experience.” International Marketing Review, 11 (6): 23-47. 
Wattanapruttipaisan (2002). "SME Subcontracting as a Bridgehead to Competitiveness: An Assessment of Supply-Side Capabilities and Demand Side Requirements.” Asia Pacific Development Journal, 9: 66-87.

Wignaraja, G. (2002). "Firm Size, Technological Capabilities and Market-Oriented Policies in Mauritius.” Oxford Development Studies, 30 (1).

Zou, S. (1998). “The Determinants of Export Performance and Review of Empirical Literature 1987-97." International Marketing Review 15 (5): 333-358 